\title{
Acidic ionic liquid-catalyzed esterification of oleic acid for biodiesel synthesis
}

\author{
Ying Li a , Shuanglan $\mathrm{Hu}^{\mathrm{a}}$, Jianhua Cheng b,\#, Wenyong Lou a,b,* \\ a School of Light Industry and Food Sciences, South China University of Technology, Guangzhou 510640, Guangdong, China \\ b State Key Laboratory of Pulp and Paper Engineering, South China University of Technology, Guangzhou 510640, Guangdong, China
}

A R T I C L E I N F O

Article history:

Received 3 October 2013

Accepted 12 December 2013

Published 20 March 2014

\section{Keywords:}

Acidic ionic liquid

Biodiesel

Oleic acid

Methanol

Esterification

\begin{abstract}
A B S T R A C T
Acidic ionic liquids (ILs) are used as environmentally-friendly and promising acid catalysts for biodiesel synthesis owing to their beneficial characteristics such as high catalytic activity, high selectivity, and ease of recycling. In this paper, seven different acidic ILs were examined as catalysts in the synthesis of biodiesel from the esterification of oleic acid with methanol. It was found that the stronger the acidity of the IL, the higher its esterification activity. The introduction of a $\mathrm{SO}_{3} \mathrm{H}$ group into the IL greatly increases its Brönsted acidity and results in a bifunctional nature of the ILs for use as either a catalyst or environmentally-friendly solution in the esterification reaction. All of these effects contribute to product formation. Of all the tested acidic ILs, 1-sulfobutyl-3-methylimidazoliumhydrosulfate $\left(\left[\mathrm{BHSO}_{3} \mathrm{MIM}\right] \mathrm{HSO}_{4}\right)$ exhibited the best catalytic performance. The $\left[\mathrm{BHSO}_{3} \mathrm{MIM}\right] \mathrm{HSO}_{4}$-catalyzed esterification of oleic acid with methanol was systematically explored, and the reaction conditions were optimized using a response surface methodology. The optimum molar ratio of methanol to oleic acid, catalyst amount, reaction temperature, and reaction time were $4: 1,10 \%$ (based on the mass of oleic acid), $130{ }^{\circ} \mathrm{C}$, and $4 \mathrm{~h}$, respectively, under these conditions, and a yield of methyl oleate (biodiesel) of $97.7 \%$ was achieved. Furthermore, [ $\left.\mathrm{BHSO}_{3} \mathrm{MIM}\right] \mathrm{HSO}_{4}$ retained around $95.6 \%$ of its original catalytic activity after 10 successive reuses ( $4 \mathrm{~h}$ per period of use), showing excellent operational stability. In addition, the use of $\left[\mathrm{BHSO}_{3} \mathrm{MIM}\right] \mathrm{HSO}_{4}$ for biodiesel synthesis from waste oils containing $72 \%$ of free fatty acids was examined, and yields as high as $94.9 \%$ after $6 \mathrm{~h}$ were obtained. Clearly, $\left[\mathrm{BHSO}_{3} \mathrm{MIM}\right] \mathrm{HSO}_{4}$ shows considerable potential for the synthesis of biodiesel.
\end{abstract}

(c) 2014, Dalian Institute of Chemical Physics, Chinese Academy of Sciences. Published by Elsevier B.V. All rights reserved.

\section{Introduction}

With the development of the global economy and increasing environmental pollution problems, the energy crisis caused by increasing global demand for energy becomes steadily more serious [1]. The environmental problems caused by the use of fossil fuels are also of great concern [2]. Because a large amount of carbon dioxide is produced from fossil fuel use and released into the atmosphere, the earth's surface temperature increases, resulting in the melting of ice sheets and a rise in sea levels. This has prompted many researchers to search for sources of efficient, safe, and renewable green energy. Biodiesel, a monoalkyl ester of fatty acids with 12-24 carbon atoms, has recently gained considerable attention in this context

\footnotetext{
* Corresponding author. Tel/Fax: +86-20-22236669; E-mail: wylou@scut.edu.cn

\# Corresponding author. Tel: +86-20-38672029; E-mail: jhcheng@scut.edu.cn

The work was supported by the National Natural Science Foundation of China $(21222606,21336002,21376096)$ and the Fundamental Research Funds for SCUT (2013ZG0003).

DOI: 10.1016/S1872-2067(14)60005-X | http://www.sciencedirect.com/science/journal/18722067 | Chin. J. Catal., Vol. 35, No. 3, March 2014
} 
[3]. It was reported that the use of $100 \%$ pure biodiesel (B100) could reduce carbon dioxide emissions by $78.5 \%$ compared with petroleum-based diesel [4]. Biodiesel is easy to transport and store because of its high flash point. The cetane number of biodiesel is high and consequently its combustion properties are good. Besides, biodiesel has other advantages such as low sulfur content, low pollution, and good lubrication performance [5]. These factors all lead to biodiesel being considered as a new type of green and renewable energy [6-8].

Esterification reactions are one way of producing biodiesel. In recent years, many investigations on catalysts for the esterification step have demonstrated the use of solid superacids [9-11], heteropoly acids [12,13], or cation-exchange resins with strong acidity $[14,15]$ as catalysts. These catalysts can displace sulfuric acid and thereby solve process problems such as equipment corrosion and environmental pollution. However, the preparation of these catalysts is relatively complicated, they are difficult to recycle, and the production cost of the catalysts is high. Therefore, it is necessary to develop an environmentally-friendly, efficient, and novel catalyst for the synthesis of biodiesel by esterification.

Ionic liquids (ILs) are salts consisting of organic cations and inorganic or organic anions, and remain liquid at room temperature or at relatively low temperatures $\left(<100^{\circ} \mathrm{C}\right)$, generally known as room temperature ILs [16]. Recently, the use of ILs for biodiesel synthesis has been extensively studied [17-20], where the ILs have been used as either liquid acid catalysts or environmentally-friendly solvents. ILs have both high acidic densities, similar to those of liquid acid catalysts, and non-volatility, similar to that of solid acid catalysts. The IL structure and acidity can be tailored by altering the cation or anion. Additionally, ILs as catalysts can be readily separated from the products and can also show high thermal stability. Therefore, ILs are expected to be a type of designer green solvent, having significant potential $[21,22]$. To date, the use of ILs as catalysts for esterification reactions has remained largely unexplored, with only a few reports available [23-26]. In the present study, the effects of various acidic ILs as catalysts on the synthesis of biodiesel from the esterification of oleic acid with methanol were examined, and the reaction conditions were optimized. In addition, the use of acidic ILs for biodiesel synthesis from waste oils containing a high content of free fatty acids was successful.

\section{Experimental}

\subsection{Materials}

1-Butyl-3-methylimidazoliumhydrosulfate ([BMIM] $\mathrm{HSO}_{4}$ ), $\mathrm{N}$-ethylpyridinium hydrosulfate ([EPy] $\left.\mathrm{HSO}_{4}\right)$, tetraethylammonium hydrosulfate ([TEAm] $\left.\mathrm{HSO}_{4}\right)$, 1-sulfobutyl-3-methylimid-

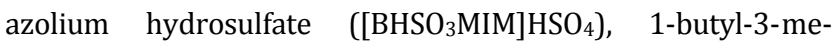

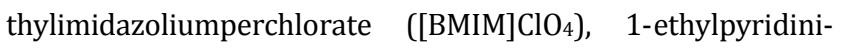
umbromide ([EPy]Br), and tetraethylammoniumchloride ([TEAm]Cl) were purchased from Lanzhou AoKe Chem. Co. Ltd (Lanzhou, China) and were of $>98 \%$ purity. Methyl oleate ( $>99 \%$ purity) and methylheptadecanoate (>97\% purity) were purchased from Sigma-Aldrich (St. Louis, USA) and TCI (Tokyo, Japan), respectively. Oleic acid and other chemicals were also obtained from commercial sources and were of the highest purity available.

\subsection{Effects of various acidic ILs on the esterification of oleic acid with methanol}

Oleic acid (2.82 g, $0.01 \mathrm{~mol}$ ), methanol ( $0.64 \mathrm{~g})$, and various acidic ILs as catalysts $(0.28 \mathrm{~g})$ were mixed in a $50 \mathrm{ml}$ round bottom flask, and then the mixture was kept at $80{ }^{\circ} \mathrm{C}$ in an oil bath (reflux condensation, magnetic stirring at $500 \mathrm{r} / \mathrm{min}$ ). Aliquots $(50 \mu \mathrm{l})$ were withdrawn and centrifuged, and the supernatant liquid ( $5 \mu \mathrm{l}$ ) was mixed with $200 \mu \mathrm{l}$ methylheptadecanoate (internal standard) prior to GC analysis.

\subsection{Optimization of $\left[\mathrm{BHSO}_{3} \mathrm{MIM}\right] \mathrm{HSO}_{4}$-catalyzed synthesis of methyl oleate via the esterification of oleic acid with methanol}

Oleic acid (2.82 g, $0.01 \mathrm{~mol}$ ) was added to a $50 \mathrm{ml}$ round bottom flask, followed by the addition of a known amount of methanol and $\left[\mathrm{BHSO}_{3} \mathrm{MIM}\right] \mathrm{HSO}_{4}$ catalyst. The mixture was heated at a predetermined temperature in an oil bath (reflux condensation, magnetic stirring at $500 \mathrm{r} / \mathrm{min}$ ). After completion of the reaction, the reaction mixture was biphasic, and the desired product (methyl oleate) stayed mainly in the upper phase. Samples $(50 \mu \mathrm{l})$ were withdrawn from the upper phase and centrifuged, and then the supernatant liquid $(5 \mu \mathrm{l})$ was mixed with $200 \mu \mathrm{l}$ methylheptadecanoate (internal standard) prior to GC analysis.

\subsection{Operational stability of the $\left[\mathrm{BHSO}_{3} \mathrm{MIM}\right] \mathrm{HSO}_{4}$ catalyst}

Oleic acid (2.82 g, $0.01 \mathrm{~mol}$ ), methanol (1.28 g), and $0.28 \mathrm{~g}$ $\left[\mathrm{BHSO}_{3} \mathrm{MIM}\right] \mathrm{HSO}_{4}$ catalyst were mixed in a $10 \mathrm{ml}$ round bottom flask at $130{ }^{\circ} \mathrm{C}$ for $4 \mathrm{~h}$ (reflux condensation, magnetic stirring at $500 \mathrm{r} / \mathrm{min}$ ). After completion of the reaction, the by-product water and excess methanol were removed from the mixture by evaporation, and then the IL catalyst $\left[\mathrm{BHSO}_{3} \mathrm{MIM}\right] \mathrm{HSO}_{4}$ was further separated from the product by centrifugation. After thorough washing with $n$-hexane followed by air-drying, the IL catalyst obtained was used in the next cycle. The activity of the $\left[\mathrm{BHSO}_{3} \mathrm{MIM}\right] \mathrm{HSO}_{4}$ catalyst in the first reaction cycle was assigned a relative activity of $100 \%$. Samples $(100 \mu \mathrm{l})$ were withdrawn from the reaction mixture at specified times for each batch and centrifuged, and the supernatant liquid ( $5 \mu \mathrm{l})$ was mixed with $200 \mu \mathrm{l}$ methylheptadecanoate (internal standard) prior to GC analysis.

\subsection{GC analysis}

The reaction mixtures were assayed using a Shimadzu GC 2010 (Tokyo, Japan) instrument equipped with an HP-5 capillary column $(0.53 \mathrm{~mm} \times 15 \mathrm{~m}$ Agilent Technologies, Inc., Santa Clara, USA) and a flame ionization detector. The column temperature was held at $180{ }^{\circ} \mathrm{C}$ for $1 \mathrm{~min}$, raised to $186^{\circ} \mathrm{C}$ at 0.8 ${ }^{\circ} \mathrm{C} / \mathrm{min}$, then kept at $186^{\circ} \mathrm{C}$ for $1 \mathrm{~min}$, followed by a further rise 
to $280{ }^{\circ} \mathrm{C}$ at $20^{\circ} \mathrm{C} / \mathrm{min}$. Nitrogen was used as the carrier gas with a flow rate of $12.5 \mathrm{ml} / \mathrm{min}$. The split ratio was $1: 25(\mathrm{v} / \mathrm{v})$. The injector and the detector temperatures were set at 250 and $280{ }^{\circ} \mathrm{C}$, respectively. The retention times for methylheptadecanoate and methyl oleate were 4.49 and $5.73 \mathrm{~min}$, respectively. The average error for this determination was $<1 \%$. All reported data were averages of experiments performed in duplicate at least. The yield of methyl oleate was calculated as Yield $=m_{(\mathrm{MO})} \times 100 \% / m$, where $m_{(\mathrm{MO})}$ is the amount of methyl oleate obtained, and $m$ is the amount of initial oils.

\section{Results and discussion}

\subsection{Effect of different acidic IL catalysts on the esterification of oleic acid with methanol}

The activity of the IL catalyst is closely related to its anion acidity and its solubility towards the substrate. During the initial stage of the esterification reaction, the acidity of the IL plays an important role in the reaction and was significantly dependent on the anion characteristics of the IL. The more acidic the anion, the stronger the IL's acidity, and this property is responsible for a marked improvement in the yield of methyl oleate. Therefore, the $\mathrm{SO}_{3} \mathrm{H}$-functioned ILs with the highest acidity exhibited a much better catalytic activity in the esterification reaction than other acidic ILs. In addition, the cation of the IL also plays a crucial role in the reaction because the hydrophilicity of the IL can be tuned mainly by the cation. This affects the miscibility of the IL with the ester product, the degree of phase separation, and the reaction efficiency [27-29]. The seven different acidic ILs tested in this present study for use in the synthesis of methyl oleate (biodiesel) gave the results depicted in Fig. 1.

As can be seen in Fig. 1, the catalytic activity of the seven acidic ILs for the esterification of oleic acid with methanol displayed the following order: $\left[\mathrm{BHSO}_{3} \mathrm{MIM}\right] \mathrm{HSO}_{4}>[\mathrm{BMIM}] \mathrm{HSO}_{4}>$

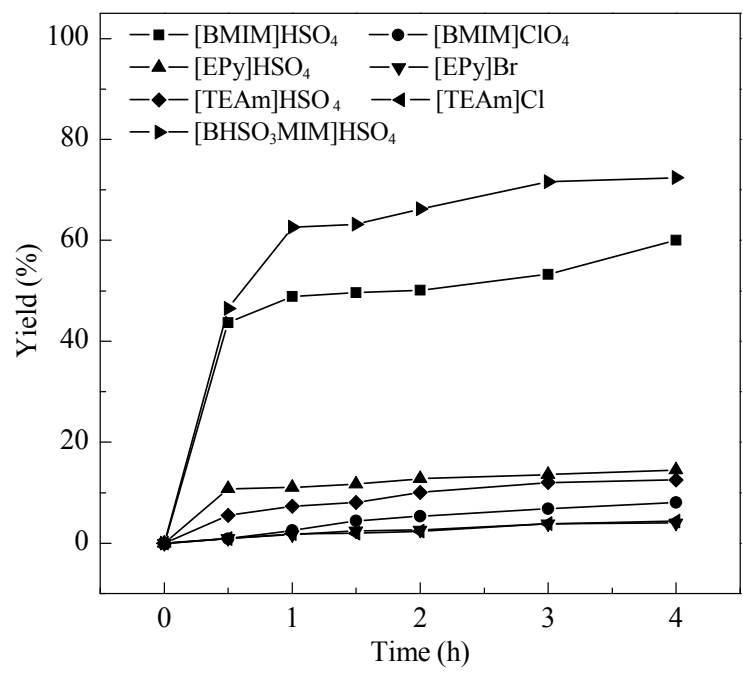

Fig. 1. Effect of various acidic IL catalysts on the esterification of oleic acid with methanol. Reaction conditions: $2.82 \mathrm{~g}$ oleic acid, $0.28 \mathrm{~g} \mathrm{IL}$ catalysts $(10 \%$ based on the mass of oleic acid), molar ratio of methanol to oleic acid $=2: 1,80^{\circ} \mathrm{C}, 500 \mathrm{r} / \mathrm{min}$.

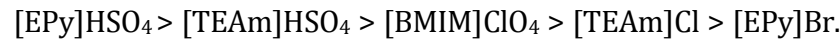
Among the ILs tested, $\left[\mathrm{BHSO}_{3} \mathrm{MIM}\right] \mathrm{HSO}_{4}$ showed the highest catalytic activity and gave the highest yield of $72.4 \%$ after reaction for $4 \mathrm{~h}$. With [BMIM] $\mathrm{HSO}_{4}$ acting as the catalyst, a relatively good yield of $60 \%$ was also achieved at a reaction time of $4 \mathrm{~h}$. Hence, $\left[\mathrm{BHSO}_{3} \mathrm{MIM}\right] \mathrm{HSO}_{4}$ was considered to be the best IL catalyst for the reaction.

\subsection{Effect of reaction temperature on the esterification of oleic acid with methanol}

Reaction temperature is an important parameter for the esterification of oleic acid with methanol, with higher temperatures always leading to faster rates, together with a shift in the esterification reaction equilibrium towards the product. In a certain range of temperatures for the esterification reaction, the reaction rate and the yield clearly increase with an increase in reaction temperature. However, there is usually no substantial improvement in the product yield when the reaction temperature is increased further. In order to explore the effect of temperature on the reaction and to find the optimum reaction temperature, the $\left[\mathrm{BHSO}_{3} \mathrm{MIM}\right] \mathrm{HSO}_{4}$-catalyzed esterification of oleic acid with methanol was carried out at different reaction temperatures $\left(60-140^{\circ} \mathrm{C}\right)$. The results obtained are illustrated in Fig. 2.

As is evident from the data depicted in Fig. 2, when the reaction temperature was lower than $120{ }^{\circ} \mathrm{C}$, the yield of methyl oleate (biodiesel) significantly increased with increasing reaction temperature. When the reaction temperature was $120^{\circ} \mathrm{C}$, the relatively high yield of $95.3 \%$ was achieved at a reaction time of $4 \mathrm{~h}$. Further increase of the reaction temperature $(>120$ ${ }^{\circ} \mathrm{C}$ ) did not lead to a significant improvement in the product yield, indicating that the reaction was close to equilibrium. Taking the energy consumption and the product yield into account, $120{ }^{\circ} \mathrm{C}$ was selected as the optimum reaction temperature for the esterification of oleic acid with methanol.

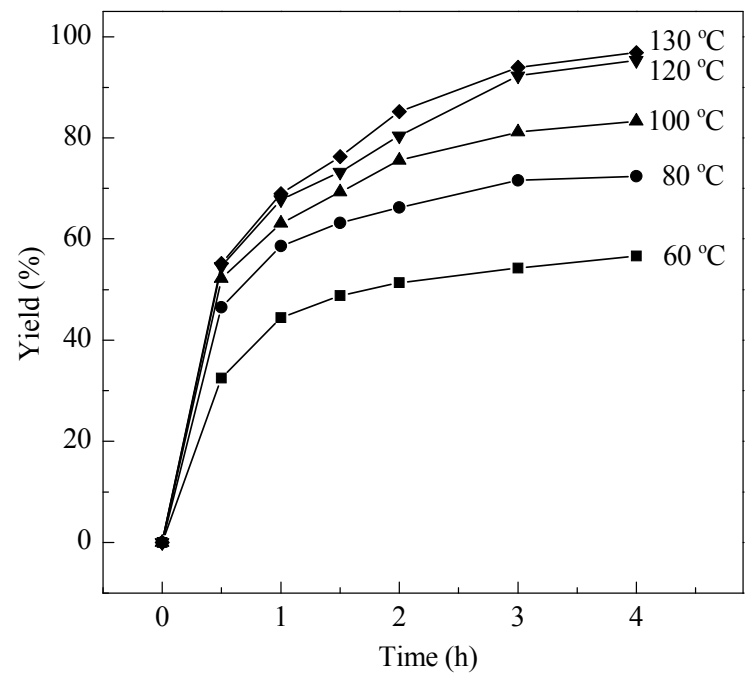

Fig. 2. Effect of reaction temperature on $\left[\mathrm{BHSO}_{3} \mathrm{MIM}\right] \mathrm{HSO}_{4}$-catalyzed esterification of oleic acid with methanol. Reaction conditions: $2.82 \mathrm{~g}$ oleic acid, $0.28 \mathrm{~g}$ [BHSO${ }_{3} \mathrm{MIM}^{2} \mathrm{HSO}_{4}$, molar ratio of methanol to oleic acid $=2: 1,500 \mathrm{r} / \mathrm{min}$. 


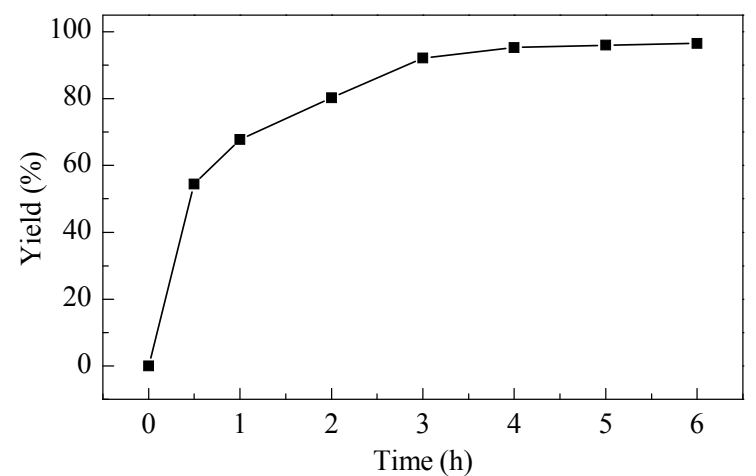

Fig. 3. Time course of the $\left[\mathrm{BHSO}_{3} \mathrm{MIM}\right] \mathrm{HSO}_{4}$-catalyzed esterification of oleic acid with methanol. Reaction conditions: $2.82 \mathrm{~g}$ oleic acid, $0.28 \mathrm{~g}$ $\left[\mathrm{BHSO}_{3} \mathrm{MIM}\right] \mathrm{HSO}_{4}$, molar ratio of methanol to oleic acid $=2: 1,120^{\circ} \mathrm{C}$, $500 \mathrm{r} / \mathrm{min}$.

\subsection{Effect of reaction time on the esterification of oleic acid with methanol}

Reaction time is also an important factor influencing the esterification reaction. Generally, with an increase in reaction time, the reaction equilibrium will shift gradually to the products, and the yield of methyl oleate will be enhanced. However, when the reaction time exceeds the time required to attain equilibrium, the yield does not increase significantly with increasing reaction time. To find the optimal reaction time for the esterification, the time course of the reaction was plotted, as depicted in Fig. 3.

Figure 3 shows that the esterification process could be divided into three phases. In the first phase, the substrate oleic acid reacted rapidly with the excess of methanol, and more than $67.8 \%$ oleic acid was converted into methyl oleate within $1 \mathrm{~h}$. In the second phase, the reaction rate gradually decreased in the period from 2 to $4 \mathrm{~h}$, and a relatively high yield of methyl oleate $(95.3 \%)$ was obtained at a reaction time of $4 \mathrm{~h}$. In the third phase, the esterification reaction moved closer to equilibrium for reaction times $>4 \mathrm{~h}$, and the yield of methyl oleate showed no significant improvement at these extended reaction times. Therefore, the optimal reaction time for the esterification was considered to be $4 \mathrm{~h}$.

\subsection{Effect of molar ratio of methanol to oleic acid on the esterification of oleic acid}

As shown in Fig. 4, when the molar ratio of methanol to oleic acid in the reaction system was $<2: 1$, the yield of methyl oleate (biodiesel) at a reaction time of $4 \mathrm{~h}$ increased significantly with increasing methanol concentration. A slight improvement in the experimental yield at $4 \mathrm{~h}$ reaction time was observed when the molar ratio of methanol to oleic acid increased from $2: 1$ to $8: 1$, and this was close to the theoretical yield. It is well known that the esterification reaction is reversible, and an excess of methanol contributes to the esterification of oleic acid and increases the reaction rate. Nevertheless, when the molar ratio of methanol to oleic acid is greater than a certain value, the amount of methanol has little effect on the reaction rate. When

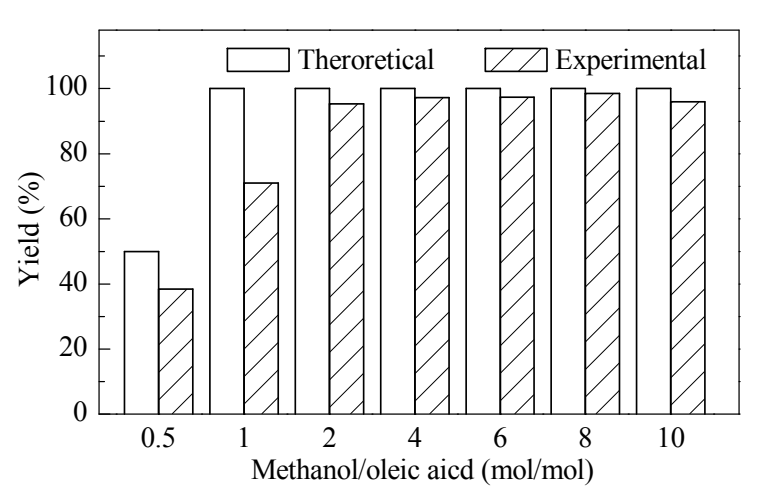

Fig. 4. Effect of molar ratio of methanol to oleic acid on the esterification reaction. Reaction conditions: $2.82 \mathrm{~g}$ oleic acid, $0.28 \mathrm{~g}$ $\left[\mathrm{BHSO}_{3} \mathrm{MIM} \mathrm{HSO}_{4}, 120^{\circ} \mathrm{C}, 4 \mathrm{~h}, 500 \mathrm{r} / \mathrm{min}\right.$.

the molar ratio of methanol to oleic acid was $>8: 1$, the yield of methyl oleate even decreased slightly with increasing molar ratio. This was probably owing to the lowered IL concentration in the reaction system. Taking the energy consumption and the yield into consideration, the optimal molar ratio of methanol to oleic acid was shown to be $4: 1$.

\subsection{Effect of $\left[\mathrm{BHSO}_{3} \mathrm{MIM}\right] \mathrm{HSO}_{4}$ catalyst dosage on the esterification of oleic acid with methanol}

As with other catalysts, the dosage of the IL catalyst $\left[\mathrm{BHSO}_{3} \mathrm{MIM}\right] \mathrm{HSO}_{4}$ significantly affects the reaction rate. Within a certain range of IL concentration, when the dosage of $\left[\mathrm{BHSO}_{3} \mathrm{MIM}\right] \mathrm{HSO}_{4}$ in the reaction system was increased, the reaction rate became markedly higher. However, when the dosage of catalyst exceeded a certain value, the reaction rate showed no significant increase with further increase in the dosage of IL catalyst, and might even have decreased. Figure 5 shows the effects of various concentrations of $\left[\mathrm{BHSO}_{3} \mathrm{MIM}\right] \mathrm{HSO}_{4}$ catalyst (expressed as a percentage based on the mass of oleic acid) on the esterification of oleic acid with methanol.

The reaction rate and the yield of methyl oleate (biodiesel)

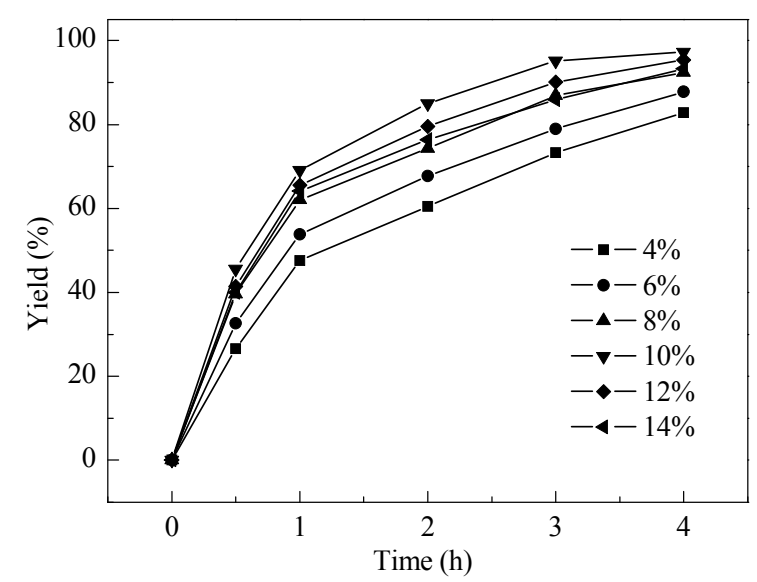

Fig. 5. Effect of dosage of IL catalyst on $\left[\mathrm{BHSO}_{3} \mathrm{MIM}\right] \mathrm{HSO}_{4}$-catalyzed esterification of oleic acid with methanol. Reaction conditions: $2.82 \mathrm{~g}$ oleic acid, molar ratio of methanol to oleic acid $=4: 1,120^{\circ} \mathrm{C}, 500 \mathrm{r} / \mathrm{min}$. 
Table 1

Factors and levels in the Box-Behnken experimental design for optimizing the synthesis of methyl oleate.

\begin{tabular}{lcccc}
\hline \multirow{2}{*}{ Name } & Coded & \multicolumn{3}{c}{ Coded level } \\
\cline { 2 - 5 } & factor & -1 & 0 & 1 \\
\hline Catalyst dosage (\%) & $\mathrm{A}$ & 8 & 10 & 12 \\
$\begin{array}{l}\text { Molar ratio of methanol } \\
\text { to oleic acid }\end{array}$ & $\mathrm{B}$ & $1: 1$ & $3: 1$ & $5: 1$ \\
Temperature $\left({ }^{\circ} \mathrm{C}\right)$ & $\mathrm{C}$ & 100 & 120 & 140 \\
\hline
\end{tabular}

were enhanced with increasing dose of $\left[\mathrm{BHSO}_{3} \mathrm{MIM} \mathrm{HSO}_{4}\right.$ catalyst from $4 \%$ to $10 \%$, and the maximum yield of $97.3 \%$ was achieved with $10 \%$ catalyst dose. However, a further increase in the catalyst dose lowered the yield. This might be attributable to the increased viscosity of the reaction system caused by adding a large amount of the IL catalyst, thereby affecting mass transfer and the reaction rate. The optimum dosage of the $\left[\mathrm{BHSO}_{3} \mathrm{MIM}\right] \mathrm{HSO}_{4}$ catalyst was therefore $10 \%$.

\subsection{Optimization of the $\left[\mathrm{BHSO}_{3} \mathrm{MIM}\right] \mathrm{HSO}_{4}$-catalyzed} esterification of oleic acid with methanol using response surface methodology (RSM)

Based on the results of single factor experiments, catalyst dose, methanol to oil molar ratio, and reaction temperature were chosen as the variables for further optimization. The esterification of oleic acid with methanol by $\left[\mathrm{BHSO}_{3} \mathrm{MIM}\right] \mathrm{HSO}_{4}$ was planned using a three-level, three factor Box-Behnken design. The experimental factors and levels are presented in Table 1.

Independent variables included catalyst dosage $(A)$, methanol to oleic acid molar ratio (B), and reaction temperature (C) with their corresponding high, medium, and low levels being represented by coded values 1,0 , and -1 , respectively. Methyl oleate yield was considered the response value, represented by Y. Table 2 shows the design matrix for the Box-Behnken experimental design together with the experimental results.

Details of the reaction were clarified through RSM and
Table 2

Arrangement and experimental results of the Box-Behnken experimental design for optimizing the synthesis of methyl oleate.

\begin{tabular}{lcccc}
\hline Entry & A & B & C & Y \\
\hline 1 & -1 & -1 & 0 & 67.3 \\
2 & -1 & 0 & 1 & 91.3 \\
3 & -1 & 0 & -1 & 79.7 \\
4 & 0 & 0 & 0 & 95.8 \\
5 & 0 & 0 & 0 & 95.4 \\
6 & 1 & -1 & 0 & 70.0 \\
7 & 1 & 0 & 1 & 92.9 \\
8 & 0 & 0 & 0 & 95.5 \\
9 & 1 & 1 & 0 & 93.2 \\
10 & 0 & -1 & -1 & 62.0 \\
11 & 0 & 0 & 0 & 96.2 \\
12 & 0 & 1 & -1 & 85.7 \\
13 & 0 & 0 & 0 & 95.8 \\
14 & 0 & 1 & 1 & 96.6 \\
15 & 1 & 0 & -1 & 82.0 \\
16 & -1 & 1 & 0 & 92.0 \\
17 & 0 & -1 & 1 & 73.4 \\
\hline
\end{tabular}

shown in Tables 3 and 4. The 3D maps of the response surface are presented in Fig. 6.

The experimental values obtained from the Box-Behnken experimental design were regressed by using a quadratic polynomial equation, and the regression equation, expressed in terms of the coded factors defined in Table 1, is given as Eq. (1):

$$
\begin{gathered}
Y=95.66+1.00 A+11.90 B+5.55 C-0.37 A B-0.18 A C- \\
0.025 B C-3.97 A^{2}-11.07 B^{2}-5.27 C^{2}
\end{gathered}
$$

The analysis of variance (ANOVA) for this model is present in Table 3 , and the significance test for each regression coefficient of the established equation is shown in Table 4. From Table 3, it was found that the $F$-value of the regression model was 3197 , which is more than $F_{0.05}(9,4)$ of 6.00 , and the $P$-value was very low $(P<0.0001)$, implying the significance of this model $(P$-values $<0.05$ are generally taken to indicate that model terms are significant).

The $F$-value of the "Lack of fit" was 0.44 , which was $<F_{0.05}(9$, 3 ) of 8.1, while the $P$-value of "Lack of fit" was $0.74,>0.05$,

Table 3

Variance analysis for the established regression equation simulating the synthesis of methyl oleate.

\begin{tabular}{lccccc}
\hline Source & $\mathrm{df}$ & SS & SM & $F$-value & $P$-value \\
\hline Model & 9 & 2145 & 238 & 3197 & $<0.0001$ \\
Residual & 7 & 0.52 & 0.075 & 0.44 & 0.74 \\
Lack of fit & 3 & 0.13 & 0.043 & &
\end{tabular}

Note: $R^{2}>0.99, R^{2}$ adj $>0.99, R_{\mathrm{SN}}=167$.

Table 4

\begin{tabular}{|c|c|c|c|c|c|c|}
\hline Factor & $\mathrm{df}$ & Coefficient estimate & Standard error & $F$-value & $P$-value & Significance \\
\hline Intercept & 1 & 95.74 & 0.12 & & & \\
\hline A & 1 & 0.98 & 0.097 & 101.98 & $<0.0001$ & ** \\
\hline B & 1 & 11.85 & 0.097 & 15064.48 & $<0.0001$ & $* *$ \\
\hline $\mathrm{C}$ & 1 & 5.60 & 0.097 & 3364.29 & $<0.0001$ & $* *$ \\
\hline $\mathrm{A}^{2}$ & 1 & -0.38 & 0.14 & 7.54 & 0.0286 & $*$ \\
\hline $\mathrm{B}^{2}$ & 1 & -0.17 & 0.14 & 1.64 & 0.2408 & \\
\hline $\mathrm{C}^{2}$ & 1 & -0.13 & 0.14 & 0.84 & 0.3904 & \\
\hline $\mathrm{AB}$ & 1 & -4.03 & 0.13 & 918.15 & $<0.0001$ & $* *$ \\
\hline $\mathrm{AC}$ & 1 & -11.08 & 0.13 & 6934.89 & $<0.0001$ & $* *$ \\
\hline $\mathrm{BC}$ & 1 & -5.23 & 0.13 & 1545.9 & $<0.0001$ & $* *$ \\
\hline
\end{tabular}

Significance test for each regression coefficient of the established regression equation simulating the synthesis of methyl oleate. 

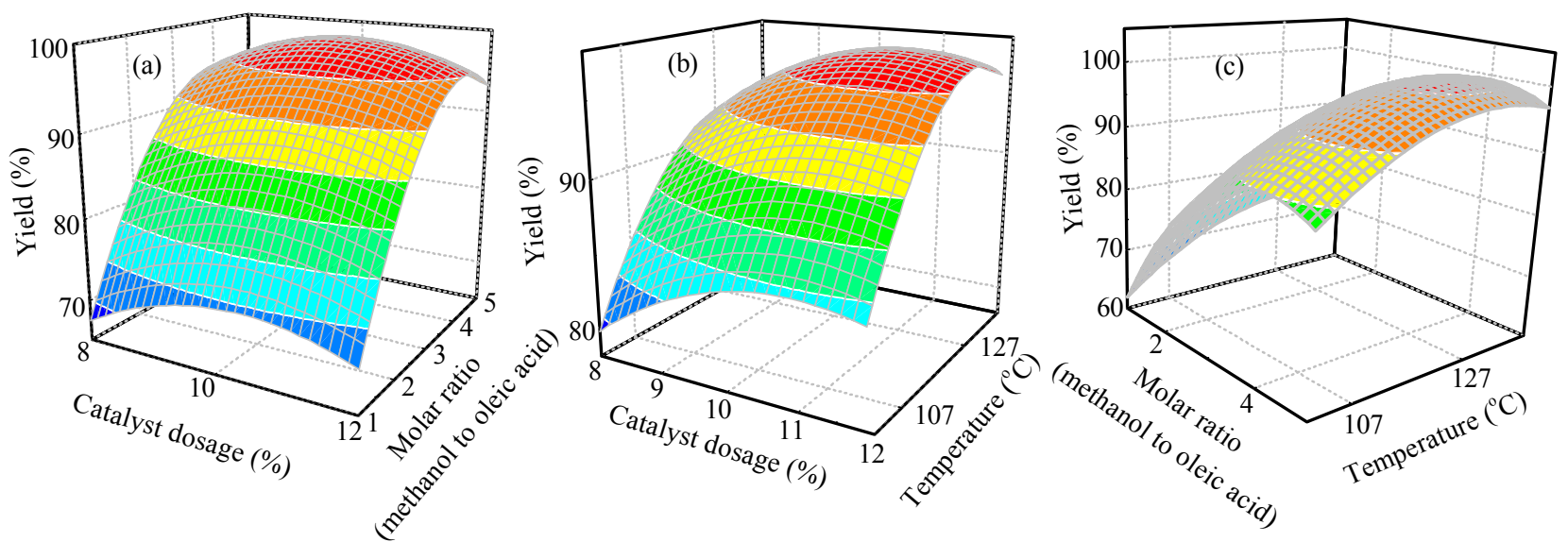

Fig. 6. (a) Effect of molar ratio and dose of the catalyst on esterification; (b) Effect of reaction temperature and dose of the catalyst on esterification; (c) Effect of reaction temperature and molar ratio on esterification.

suggesting that the Lack of fit of this regression equation was not significant. The adjusted $R$ squared $\left(R^{2}\right.$ adj $)$ was above 0.99 , indicating that this model could explain $74 \%$ of the response. Moreover, $R^{2}$ was above 0.99 (close to 1 ), implying that the actual values were very close to the predicted values and this showed that the model was reliable for predicting and analyzing the methyl oleate yield.

The optimum levels of the factors investigated can be deduced from Eq. (1), obtained from multiple regression analysis, and it was found that the maximum yield of methyl oleate was predicted to be $100 \%$. Further, the model predicted that the maximum value would be obtained when the IL catalyst dosage was $9.7 \%$, methanol to oleic acid molar ratio was 3.4:1, and the reaction temperature was $131.4{ }^{\circ} \mathrm{C}$. To simplify operations, $10 \%$ catalyst, 4:1 molar ratio of methanol to oleic acid, and 130 ${ }^{\circ} \mathrm{C}$ were used, and the yield of methyl oleate was $97.7 \%$, very close to the predicted value. This result clearly confirmed the validity of this model.

\subsection{The operational stability of the $\left[\mathrm{BHSO}_{3} \mathrm{MIM}\right] \mathrm{HSO}_{4}$ catalyst}

The operational stability of the catalyst directly affects its application in semi-continuous and automated production processes. Catalysts having a high operational stability always exhibit excellent reusability, thereby reducing the costs of methyl oleate (biodiesel) production. To evaluate the recycling performance of the $\left[\mathrm{BHSO}_{3} \mathrm{MIM}\right] \mathrm{HSO}_{4}$ catalyst, the operational stability of $\left[\mathrm{BHSO}_{3} \mathrm{MIM}\right] \mathrm{HSO}_{4}$ was investigated by using the esterification of oleic acid with methanol as a model reaction under the optimized conditions described above. As is evident in Fig. 7, the IL catalyst $\left[\mathrm{BHSO}_{3} \mathrm{MIM}\right] \mathrm{HSO}_{4}$ still retained about $95.6 \%$ of its original catalytic activity even after 10 cycles of successive reuse ( $4 \mathrm{~h}$ per cycle) and gave the relatively high yield of methyl oleate of $93.2 \%$. The performance demonstrates the outstanding activity and excellent operational stability of the $\left[\mathrm{BHSO}_{3} \mathrm{MIM}\right] \mathrm{HSO}_{4}$ catalyst.

\section{8. [BHSO $\mathrm{BIM}_{3} \mathrm{HSO}_{4}$-catalyzed conversion of different feedstocks into biodiesel}

The above results clearly demonstrate that the acidic IL $\left[\mathrm{BHSO}_{3} \mathrm{MIM}\right] \mathrm{HSO}_{4}$ is effective in catalyzing the esterification of oleic acid with methanol to methyl oleate. To expand the applicability of the IL catalyst for different feedstocks, the [BHSO $\left.{ }_{3} \mathrm{MIM}\right] \mathrm{HSO}_{4}$-catalyzed conversion of other feedstocks (palmitic acid and waste oils with high acid value) to biodiesel as investigated, and the results are summarized in Table 5. $\left[\mathrm{BHSO}_{3} \mathrm{MIM}\right] \mathrm{HSO}_{4}$ was also capable of efficiently catalyzing the esterification of palmitic acid with methanol and gave $94.7 \%$ yield of methyl palmitate (biodiesel) after reaction for $4 \mathrm{~h}$ at $130{ }^{\circ} \mathrm{C}$. It is worth noting that $\left[\mathrm{BHSO}_{3} \mathrm{MIM}\right] \mathrm{HSO}_{4}$ afforded $88.5 \%$ yield of biodiesel at a reaction time of $4 \mathrm{~h}$ and $130{ }^{\circ} \mathrm{C}$ when waste oils with $72 \%$ free fatty acids (FFAs) were used as feedstock. It is well known that the esterification and transesterification reactions occur simultaneously in the $\left[\mathrm{BHSO}_{3} \mathrm{MIM}\right] \mathrm{HSO}_{4}$-catalyzed conversion of waste oils with a high content of FFAs. Because the rate of transesterification was much lower than that of esterification, the reaction temperature for conversion of waste oils was raised from 130 to $140{ }^{\circ} \mathrm{C}$, and the yield of biodiesel at a reaction time of $6 \mathrm{~h}$ was

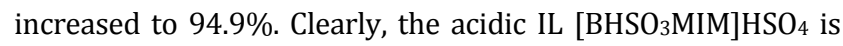

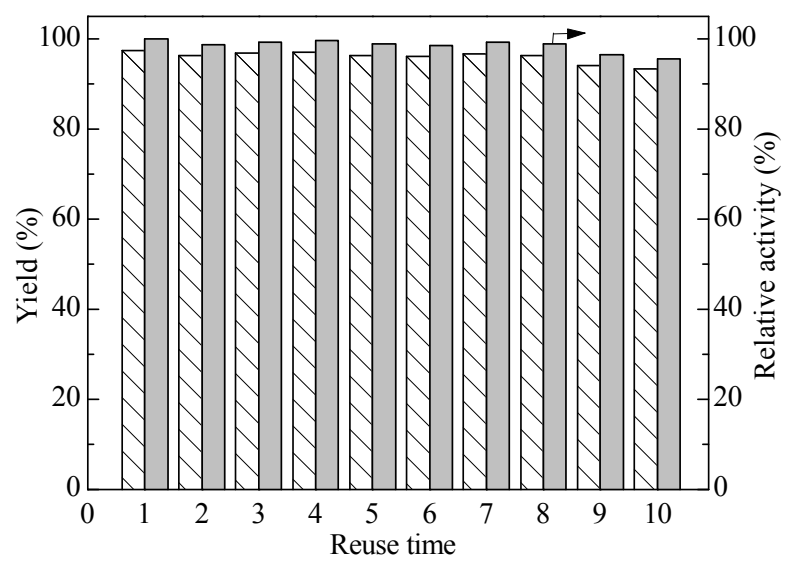

Fig. 7. Reusability of $\left[\mathrm{BHSO}_{3} \mathrm{MIM}\right] \mathrm{HSO}_{4}$ for the esterification of oleic acid with methanol. Reaction conditions: $2.82 \mathrm{~g}$ oleic acid, $0.28 \mathrm{~g}$ $\left[\mathrm{BHSO}_{3} \mathrm{MIM} \mathrm{HSO}_{4}\right.$, molar ratio of methanol to oleic acid of $4: 1,130^{\circ} \mathrm{C}, 4$ h, $500 \mathrm{r} / \mathrm{min}$. 
Table 5

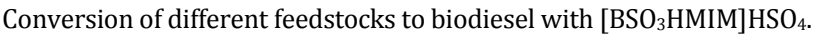

\begin{tabular}{lccc}
\hline Feedstock & $T\left({ }^{\circ} \mathrm{C}\right)$ & Time $(\mathrm{h})$ & Yield $(\%)$ \\
\hline Oleic acid $^{\mathrm{a}}$ & 130 & 4 & 97.7 \\
Palmitic acid $^{\mathrm{a}}$ & 130 & 4 & 94.7 \\
Waste oils $^{\mathrm{b}}$ & 130 & 4 & 88.5 \\
& 140 & 6 & 94.9 \\
\hline
\end{tabular}

a Molar ratio of methanol to fatty acid $=4: 1$, and the amount of the IL catalyst was $10 \%$ based on the mass of fatty acid.

b Waste cooking oils contained 72\% FFAs. Molar ratio of methanol to oil was $8: 1$, and the amount of the IL catalyst was $10 \%$ based on the mass of waste oils.

able to efficiently catalyze the conversion of different feedstocks, especially waste oils with high acid value, into biodiesel.

\section{Conclusions}

The above-described results clearly showed that the stronger the acidity of IL, the higher its esterification activity. Among all the acidic ILs tested, $\left[\mathrm{BHSO}_{3} \mathrm{MIM}\right] \mathrm{HSO}_{4}$ provided the best results for the synthesis of methyl oleate (biodiesel) from the esterification of oleic acid with methanol, and the yield of methyl oleate obtained reached $97.7 \%$. $\left[\mathrm{BHSO}_{3} \mathrm{MIM}\right] \mathrm{HSO}_{4}$ was also used for the esterification of palmitic acid with methanol and in the conversion of waste oils with high acid value (with $72 \%$ FFAs) to biodiesel. Clearly, $\left[\mathrm{BHSO}_{3} \mathrm{MIM}\right] \mathrm{HSO}_{4}$ shows great potential for converting different feedstocks into biodiesel.

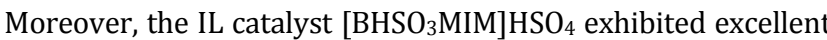
operational stability. This system can provide a green, safe, and feasible means for the industrial production of biodiesel.

\section{References}

[1] Fan X H, Burton R. Open Fuels Energy Sci J, 2009, 2: 100

[2] Amin S. Energy Convers Manage, 2009, 50: 1834

[3] Min E Z. J Chem Ind Eng (China) (闵恩泽. 化工学报), 2006, 57: 1739

[4] Sheehan J, Camobreco V, Duffield J, Graboski M, Shapouri H. Overview of Biodiesel and Petroleum Diesel Life Cycles. US: National Renewable Energy Lab, Golden, CO, 2000

[5] Min E Z, Zhang L X. Development of Biodiesel Industry Chain - Biodiesel Refinery and Chemical Plant. Beijing: China Petrochemical Press (闵恩泽, 张利雄. 生物柴油产业链的开拓: 生物柴油炼油化 工厂. 北京: 中国石化出版社), 2006.191
[6] Zhang X Y, Ma Q, Cheng B B, Wang J, Li J S, Nie F D. J Nat Gas Chem, 2012, 21: 774

[7] Intarapong $\mathrm{P}$, Iangthanarat $\mathrm{S}$, Phanthong $\mathrm{P}$, Luengnaruemitchai $\mathrm{A}$, Jai-In S.J Energy Chem, 2013, 22: 690

[8] Du Z X, Tang Z, Wang H J, Zeng J L, Chen Y F, Min E Z. Chin J Catal (杜泽学, 唐忠, 王海京, 曾建立, 陈艳风, 闵恩泽. 催化学报), 2013, 34: 101

[9] Komintarachat C, Chuepeng S. Ind Eng Chem Res, 2009, 48: 9350

[10] Hu X T, Zhou Z, Sun D F, Wang Y T, Zhang Z B. Catal lett, 2009, 133 90

[11] Li M, Chen D Y, Zhu X F. Chin J Catal (李明, 陈登宇, 朱锡锋. 催化 学报), 2013, 34: 1674

[12] Alsalme A, Kozhevnikova E F, Kozhevnikov I V. Appl Catal A, 2008, 349: 170

[13] Katada N, Hatanaka T, Ota M, Yamada K, Okumura K, Niwa M. Appl Catal A, 2009, 363: 164

[14] Blagov S, Parada S, Bailer O, Moritz P, Lam D, Weinand R, Hasse H. Chem Eng Sci, 2006, 61: 753

[15] Toukoniitty B, Mikkola J P, Eranen K, Salmi T, Murzin D Y. Catal Today, 2005, 100: 431

[16] Den Y Q. Fine Chem Raw Mater Intermediates (邓友全. 精细化工原 料及中间体), 2007, (10): 3

[17] Elsheikh Y A, Man Z, Bustam M A, Yusup S, Wilfred C D. Energy Convers Manage, 2011, 52: 804

[18] Ghiaci M, Aghabarari B, Habibollahi S, Gil A. Bioresource Technol, 2011, 102: 1200

[19] Han M H, Yi W L, Wu Q, Liu Y, Hong Y C, Wang D Z. Bioresource Technol, 2009, 100: 2308

[20] Wu Q, Chen H, Han M M, Wang D Z, Wang J F. Ind Eng Chem Res, 2007, 46: 7955

[21] Liang X Z, Gong G Z, Wu H H, Yang J G. Fuel, 2009, 88: 613

[22] Yang D, Xie W L, Wang J L. China Oils Fats (杨栋, 谢文否, 王建龙. 中国油脂), 2010, 35: 54

[23] Fang D, Yang J M, Jiao C M. ACS Catal, 2010, 1: 42

[24] Gui J Z, Cong X H, Liu D, Zhang X T, Hu Z D, Sun Z L. Catal Commun, 2004, 5: 473

[25] Zhang L, Xian M, He Y C, Li L Z, Yang J M, Yu S T, Xu X. Bioresource Technol, 2009, 100: 4368

[26] Zhen B, Li H S, Jiao Q Z, Li Y, Wu Q, Zhang Y P. Ind Eng Chem Res, 2012, 51: 10374

[27] Bo Y, Zhang L M, Man R L. J Lanzhou Univ Technol (柏杨, 张立明, 满瑞林. 兰州理工大学学报), 2010, 36(3): 81

[28] Shi N, Huang B H, Wang Y F, Li Z J,Zhang K, Fang Y X. Chem Reagents (史娜, 黄宝华, 汪艳飞, 黎子进, 张焜, 方岩雄. 化学试剂), 2009, 31: 423

[29] Tao D J, Zhou Z, Lü X M, Hu X B, Wu Y T. Modern Chem Ind (陶端健, 周政, 吕学铭, 胡兴邦, 吴有庭. 现代化工), 2011, 31(1): 20

\section{Graphical Abstract}

Chin. J. Catal., 2014, 35: 396-406 doi: 10.1016/S1872-2067(14)60005-X

Acidic ionic liquid-catalyzed esterification of oleic acid for biodiesel synthesis

Ying Li, Shuanglan Hu, Jianhua Cheng *, Wenyong Lou*

South China University of Technology

The esterification of oleic acid with methanol was successfully conducted with acidic ionic liquids as catalysts. $\left[\mathrm{BHSO}_{3} \mathrm{MIM}\right] \mathrm{HSO}_{4}$ exhibited the best results and could also efficiently catalyze the conversion of waste oils to biodiesel.

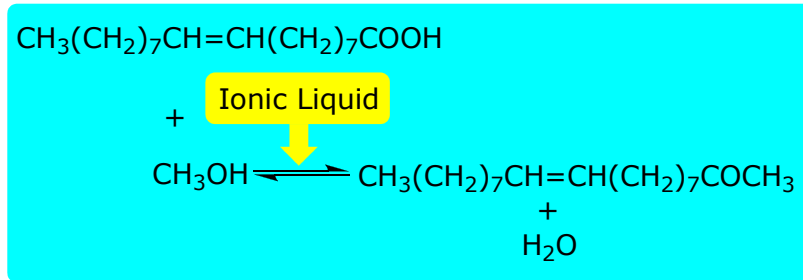




\title{
酸性离子液体催化油酸酯化合成生物柴油
}

\author{
李 颖 ${ }^{\mathrm{a}}$, 胡双岗 ${ }^{\mathrm{a}}$, 程建华 ${ }^{\mathrm{b}, \# \text {, 娄文勇 }}{ }^{\mathrm{a}, \mathrm{b}, *}$ \\ a华南理工大学轻工与食品学院, 广东广州510640 \\ b华南理工大学制浆造纸工程国家重点实验室，广东广州510640
}

摘要: 酸性离子液体具有催化活性好、选择性高及易于回收等优点, 是一种应用前景非常好的环境友好的酸性催化剂, 在生物柴 油合成反应中具有重大的理论意义和应用价值. 本文以油酸和甲醇为原料, 探讨了7种不同酸性离子液体在生物柴油合成反应中 的催化效应. 研究表明, 离子液体酸性越强, 催化酯化活性越高; 引入磺酸基团可大大增强离子液体Brönsted酸性, 使其在酯化反 应中发挥溶剂/催化剂的双重作用, 促进酯化反应向产物方向进行, 达到高产率, 因而1-丁基磺酸-3-甲基咪唑硫酸氢盐 $\left(\left[\mathrm{BHSO}_{3} \mathrm{MIM}\right] \mathrm{HSO}_{4}\right)$ 催化效果最好. 此外, 系统研究了 $\left[\mathrm{BHSO}_{3} \mathrm{MIM}\right] \mathrm{HSO}_{4}$ 催化油酸与甲醇酯化反应, 并采用响应面法优化了反应 条件. 结果发现, 该反应的最适醇酸摩尔比、催化剂用量、反应温度及反应时间分别为 $4: 1,10 \%$ (基于油酸的质量), $130{ }^{\circ} \mathrm{C}$ 和 $4 \mathrm{~h}$; 在 此条件下, 生物柴油产率为 $97.7 \%$. [ $\mathrm{BHSO}_{3} \mathrm{MIM}^{\mathrm{N}} \mathrm{HSO}_{4}$ 连续使用 10 批次后, 仍能保持初始催化活性的 $95.6 \%$, 表现出极好的操作稳 定性. 另外, 利用该离子液体催化游离脂肪酸含量为 $72 \%$ 的废油脂生产生物柴油, 反应 $6 \mathrm{~h}$ 可获得产率 $94.9 \%$. 可见， $\left[\mathrm{BHSO}_{3} \mathrm{MIM}\right] \mathrm{HSO}_{4}$ 在酯化生产生物柴油方面具有巨大的应用潜力.

关键词: 酸性离子液体; 生物柴油; 油酸; 甲醇; 酯化

收稿日期: 2013-10-03. 接受日期: 2013-12-12. 出版日期: 2014-03-20.

*通讯联系人. 电话/传真: (020)22236669; 电子信箱: wylou@scut.edu.cn

\#通讯联系人. 电话: (020)38672029; 电子信箱: jhcheng@scut.edu.cn

基金来源：国家自然科学基金(21222606, 21336002, 21376096); 华南理工大学中央高校基本科研业务费资助项目(2013ZG0003).

本文的英文电子版由Elsevier出版社在ScienceDirect上出版(http://www.sciencedirect.com/science/journal/18722067).

\section{1. 前言}

随着全球经济发展和环境污染问题不断加剧, 全球 能源需求不断增加, 由此引起了能源危机 ${ }^{[1]}$. 化石燃料 对环境造成的问题也令人堪忧 ${ }^{[2]}$ 二氧化碳大量释放, 地 表温度增加, 导致冰川融化, 海平面上升. 因此越来越多 的研究者开始寻找高效、安全、环保的可再生能源. $\mathrm{C}_{12}-\mathrm{C}_{24}$ 的脂肪酸单烷基酯简称生物柴油 ${ }^{[3]}$, 研究表明, 与石化柴油相比, 使用 $100 \%$ 纯生物柴油(B100)可以减少 $78.45 \%$ 的二氧化碳排放量 ${ }^{[4]}$. 生物柴油闪点高, 便于运 输和存储; 十六烷值高, 燃烧性能好; 含硫量低, 对环境 污染小; 具有较好的润滑性能 ${ }^{[5]}$. 因此, 生物柴油是一种 新型绿色可再生能源 ${ }^{[6,7]}$.

酯化是一种合成生物柴油的方法, 近年来, 随着对 酯化催化剂的深入研究, 人们发现采用固体超强酸 ${ }^{[8,9]}$ 、 杂多酸 ${ }^{[10,11]}$ 和强酸性阳离子交换树脂 ${ }^{[12,13]}$ 代替浓硫酸作 为酯化催化剂, 虽然可以解决设备腐蚀和环境污染等问 题, 但此类催化剂的制备过程较复杂, 催化剂不易再生, 且成本也较高. 因此, 开发环境友好的新型酯化催化剂 是当前研究的热点.

离子液体是由有机阳离子和无机或有机阴离子构 成的在室温或较低温度 $\left(<100{ }^{\circ} \mathrm{C}\right)$ 下呈液态的盐类, 通常 称为室温离子液体 ${ }^{[14]}$. 离子液体在生物柴油合成研究
中的应用 ${ }^{[15-18]}$ 已相当广泛, 它作为一种新型的环境友好 溶剂和液体酸催化剂, 同时拥有液体酸的高密度反应活 性和固体酸的不挥发性, 其分子结构和酸性具有可调控 性, 催化剂和产物易分离, 热稳定性高, 将有望成为真正 意义上可设计的绿色溶剂, 而且具有很好的应用前 景 ${ }^{[19,20]}$ 和较大的工业化生产价值. 鉴于目前离子液体在 酯化反应中的应用研究不多 ${ }^{[21-24]}$, 本文探讨了不同的酸 性离子液体作为催化剂催化油酸与甲醇酯化合成生物 柴油的催化活性, 并优化了其反应条件, 同时还考察了 酸性离子液体在催化高酸值废油脂合成生物柴油过程 中的使用效果.

\section{2. 实验部分}

\section{1. 主要试剂}

1-丁基-3-甲基咪唑硫酸氢盐([BMIM] $\mathrm{HSO}_{4}$ )、 $\mathrm{N}$-乙 基吡啶硫酸氢盐 $\left([\mathrm{EPy}] \mathrm{HSO}_{4}\right)$ 、四乙基铵硫酸氢盐 ([TEAm $\left.] \mathrm{HSO}_{4}\right) 、 1$ - 丁基磺酸-3-甲基咪唑硫酸氢盐 $\left(\left[\mathrm{BHSO}_{3} \mathrm{MIM}^{-} \mathrm{HSO}_{4}\right) 、 1\right.$ - 丁基-3-甲基咪唑高氯酸盐 ([BMIM] $\mathrm{ClO}_{4}$ )、1-乙基吡啶溴盐([EPy]Br)和四乙基铵氯 盐([TEAm]Cl)均购自兰州奥力科化工有限公司; 油酸甲 酯为色谱纯, 购自 Sigma公司; 十七碳酸甲酯(内标)为色 谱纯, 购自 TCI公司; 油酸、甲醇等其他试剂均为市售分 析纯. 


\section{2. 不同酸性离子液体催化油酸与甲醇的酯化反应}

在 $50 \mathrm{ml}$ 三口圆底烧瓶中加入 $2.82 \mathrm{~g}(0.01 \mathrm{~mol})$ 油酸、 $0.64 \mathrm{~g}$ 甲醇和 $0.28 \mathrm{~g}$ 催化剂, 混合均匀, 置于 $80^{\circ} \mathrm{C}$ 的油浴 中开始反应(冷凝回流, 磁力摚拌速度为 $500 \mathrm{r} / \mathrm{min}$ ). 定 时从反应液中取样 $50 \mu \mathrm{l}$, 高速离心 $(10000 \mathrm{r} / \mathrm{min}, 7 \mathrm{~min})$, 取 $5 \mu \mathrm{l}$ 上清液与 $200 \mu \mathrm{l}$ 内标溶液(十七碳酸甲酯)混合振荡 均匀, 取 $1 \mu \mathrm{l}$ 进行气相色谱分析.

\section{3. $\left[\mathrm{BHSO}_{3} \mathrm{MIM}\right] \mathrm{HSO}_{4}$ 催化油酸与甲醇酯化合成油 酸甲酯的优化}

在 $50 \mathrm{ml}$ 三口圆底烧瓶中加入 $2.82 \mathrm{~g}(0.01 \mathrm{~mol})$ 油酸, 然后加入一定质量比的催化剂和一定醇酸摩尔比的甲 醇, 混合均匀, 置于反应温度下的油浴中开始反应(冷凝 回流, 磁力搅拌速度为 $500 \mathrm{r} / \mathrm{min}$ ). 反应结束后, 静置分 层, 分出产物相. 定时从反应液中取样 $50 \mu \mathrm{l}$, 高速离心 (10000 r/min, $7 \mathrm{~min}$ ), 取 $5 \mu \mathrm{l}$ 上清液与 $200 \mu \mathrm{l}$ 内标溶液(十 七碳酸甲酯)混合振荡均匀, 取 $1 \mu \mathrm{l}$ 进行气相色谱分析.

\section{4. $\left[\mathrm{BHSO}_{3} \mathrm{MIM}\right] \mathrm{HSO}_{4}$ 催化剂的操作稳定性}

在 $10 \mathrm{ml}$ 圆底烧瓶中装入 $2.82 \mathrm{~g}$ 油酸、 $1.28 \mathrm{~g}$ 甲醇和 $0.28 \mathrm{~g}\left[\mathrm{BHSO}_{3} \mathrm{MIM}\right] \mathrm{HSO}_{4}$ 催化剂, 置于 $130{ }^{\circ} \mathrm{C}$ 油浴中开 始反应(冷凝回流), $4 \mathrm{~h}$ 后终止反应. 将反应混合液进行 旋转蒸发除去未反应的甲醇和反应生成的水, 再将产物 与离子液体通过离心进行分离, 得到的离子液体用适量 正己烷清洗, 室温晾干后进行下一批次循环使用. 第一 批次反应的 $\left[\mathrm{BHSO}_{3} \mathrm{MIM}\right] \mathrm{HSO}_{4}$ 催化剂的活性定义为相 对活性 $100 \%$. 从每批次的反应液中取样 $100 \mu \mathrm{l}$, 离心 (10000 r/min, $7 \mathrm{~min}$ ), 取 $5 \mu \mathrm{l}$ 上清液与 $200 \mu \mathrm{l}$ 内标溶液(十 七碳酸甲酯)混合振荡均匀, 取 $1 \mu \mathrm{l}$ 进行气相色谱分析.

\section{5. 气相色谱分析}

采用日本岛津公司GC-2010型气相色谱仪进行分 析, FID检测器, 毛细管色谱柱为美国 Agilent 公司HP-5 (柱长 $15 \mathrm{~m}$, 内径 $0.53 \mathrm{~mm}$, 膜厚 $1.50 \mu \mathrm{m}$ ). 分析条件为气 化室温度 $250{ }^{\circ} \mathrm{C}$, 检测室温度 $280{ }^{\circ} \mathrm{C}$, 柱温 $180^{\circ} \mathrm{C}$, 维持 1 $\min$, 以 $0.8^{\circ} \mathrm{C} / \mathrm{min}$ 的速率升温至 $186{ }^{\circ} \mathrm{C}$, 维持 $1 \mathrm{~min}$, 再以 $20{ }^{\circ} \mathrm{C} / \mathrm{min}$ 的速率升高到 $280^{\circ} \mathrm{C}$; 载气为氮气, 流速为 $12.5 \mathrm{ml} / \mathrm{min}$; 分流比为 $25: 1$; 进样量为 $1 \mu 1$. 在该分析条 件下, 十七碳酸甲酯和油酸甲酯的保留时间分别是 4.488 和 5.734. 该分析方法条件稳定, 重现性好, 分析的最大 相对误差为 $1 \%$. 根据公式Yield $=m_{(\mathrm{MO})} \times 100 \% / m$ 计算甲 酯产率, 其中 $m_{(\mathrm{MO})}$ 为反应生成的甲酯质量, $m$ 为反应前 油酸的质量.

\section{3. 结果与讨论}

\section{1. 不同酸性离子液体催化剂对油酸酯化反应的影响}

离子液体催化剂的活性与其阴离子的酸强度和离 子液体溶解度密切相关. 反应初始阶段, 离子液体酸强 度对反应起重要作用. 离子液体的酸性很大程度上决定 于阴离子, 阴离子的酸性越强, 则离子液体酸性越强, 获 得产物的产率也越高. 引入磺酸基团的离子液体酸性最 强, 将其应用到酯化反应, 其催化活性是其它酸性离子 液体不能比拟的. 同时, 离子液体的阳离子对反应也有 决定性作用, 阳离子主要调控离子液体的亲水性, 离子 液体与酯产物的互溶性决定了其与产物分相的难易程 度, 而分相性能对催化效果有较大的影响, 从而影响催 化活性 ${ }^{[25-27]}$. 本实验考察了7种不同酸性离子液体催化 油酸酯化合成油酸甲酯的进程曲线, 结果见图1. 由图可 知, 7种离子液体催化剂的活性顺序为: [ $\left.\mathrm{BHSO}_{3} \mathrm{MIM}\right]-$

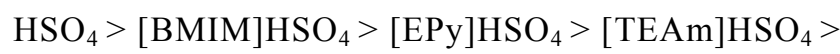
$\left[\mathrm{BMIM}^{2} \mathrm{CIO}_{4}>[\mathrm{TEAm}] \mathrm{Cl}>[\mathrm{EPy}] \mathrm{Br}\right.$. $\left[\mathrm{BHSO}_{3} \mathrm{MIM}\right] \mathrm{HSO}_{4}$ 催化油酸酯化的活性最高, 反应 $4 \mathrm{~h}$ 时, 所得产率为 $72.4 \%$; 以 $[\mathrm{BMIM}] \mathrm{HSO}_{4}$ 为催化剂时产率也较高 $(60 \%)$.

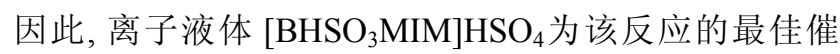
化剂.

\section{2. 反应温度对油酸酯化反应的影响}

温度是影响酯化反应的一个重要参数, 随着反应温 度的升高, 反应速度加快, 同时有利于反应平衡向产物 生成的方向移动, 提高酯化率. 为了确定 [ $\left.\mathrm{BHSO}_{3} \mathrm{MIM}\right]-$ $\mathrm{HSO}_{4}$ 催化油酸酯化反应的最适温度, 研究了 $60-140{ }^{\circ} \mathrm{C}$ 油浴条件下油酸与甲醇的酯化反应, 结果见图2. 由图可 知, 当反应温度低于 $120^{\circ} \mathrm{C}$ 时, 甲酯产率随着温度的升高 而显著增加; 当反应温度为 $120^{\circ} \mathrm{C}$ 时, 反应 $4 \mathrm{~h}$ 时, 产率为 95.3\%; 继续升高温度, 酯化产率增加并不显著, 表明反 应已接近平衡. 综合考虑能耗与产率, 选择 $120^{\circ} \mathrm{C}$ 为最 佳反应温度.

\section{3. 反应时间对油酸酯化反应的影响}

反应时间也是影响酯化反应的一个重要参数, 随着 反应时间的延长, 反应平衡向产物生成的方向移动, 油 酸甲酯产率增加. 但超过反应的平衡时间时, 随着时间 的延长, 酯化率将不再提高. 为了确定 $\left[\mathrm{BHSO}_{3} \mathrm{MIM}\right]-$ $\mathrm{HSO}_{4}$ 催化剂催化油酸甲酯化的最适反应时间, 本实验 研究了油酸甲酯化反应的过程曲线, 结果见图 3 , 可以看 出, 酯化反应可以分为三个阶段: 第一阶段, 大量的甲醇 与油酸迅速相互作用, $1 \mathrm{~h}$ 内超过 $67.8 \%$ 的油酸转化成油 酸甲酯; 第二阶段, 酯化反应速率从 $2 \mathrm{~h}$ 到 $4 \mathrm{~h}$ 逐步减慢, 反应 $4 \mathrm{~h}$ 时产率达 $95.3 \%$; 第三阶段, 反应 $4 \mathrm{~h}$ 后, 酯化反 
应趋向平衡, 甲酯产率无明显增加. 因此选择 $4 \mathrm{~h}$ 为最佳 的反应时间.

\section{4. 醇酸摩尔比对油酸酯化反应的影响}

由图 4 可知, 当反应体系中醇酸摩尔比 $\leqslant 2$ 时, 反应 4 $\mathrm{h}$, 油酸甲酯产率随着甲醇浓度的增加而显著增加. 当醇 酸摩尔比在 $2-8$ 时, 反应 $4 \mathrm{~h}$, 油酸甲酯产率随着甲醇浓度 的增加而继续增加, 但增加幅度不显著, 且均接近理论 值, 这是由于酯化反应为可逆反应, 过量的甲醇有利于 酯化反应, 因为甲醇过量可促进酯化反应速率, 有利于 产物生成. 当醇酸摩尔比超过 8 时, 反应 $4 \mathrm{~h}$, 油酸甲酯产 率随醇酸摩尔比的增大而有所下降, 这是因为大量的甲 醇存在会稀释油酸与离子液体的浓度. 综合考虑能耗和 产率, 选择最适醇酸摩尔比为 $4: 1$.

\section{5. $\left[\mathrm{BHSO}_{3} \mathrm{MIM}\right] \mathrm{HSO}_{4}$ 用量对酯化反应的影响}

$\left[\mathrm{BHSO}_{3} \mathrm{MIM}\right] \mathrm{HSO}_{4}$ 作为离子液体催化剂, 与其他催 化剂一样, 其催化反应速率直接取决于其浓度的大小. 在一定浓度范围内, $\left[\mathrm{BHSO}_{3} \mathrm{MIM}\right] \mathrm{HSO}_{4}$ 催化剂用量越 大, 反应速率越快. 但当其用量大于某一定值时, 增加催 化剂的用量对反应速率就几乎没有影响, 甚至会降低反

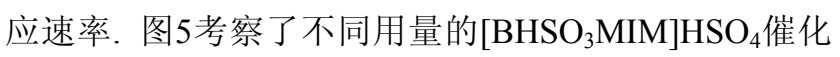
剂对酯化反应的影响. 当 $\left[\mathrm{BHSO}_{3} \mathrm{MIM}\right] \mathrm{HSO}_{4}$ 催化剂用 量在 $4 \%-10 \%$ 时, 酯化反应速率随着催化剂用量的增加 而增加, 产率提高, 且当 $\left[\mathrm{BHSO}_{3} \mathrm{MIM}\right] \mathrm{HSO}_{4}$ 添加量为 $10 \%$ 时, 产率达到最大值 $97.3 \%$. 随后, 继续增大催化剂 用量, 酯化产率稍有下降. 加入大量的离子液体会使反 应体系粘度升高, 从而降低了传质速率和反应速率. 因 此, 该反应最适的 $\left[\mathrm{BHSO}_{3} \mathrm{MIM}\right] \mathrm{HSO}_{4}$ 用量为 $10 \%$.

\section{6. 采用响应面分析法对油酸酯化反应条件的优化}

根据单因素实验结果, 选取催化剂用量、醇酸摩尔 比和反应温度 3 个影响显著的因素作为响应面试验的 3 个因素, 采用统计软件Design-Expert中的响应曲面法建 立三因素三水平的Box-Behnken模型对油酸酯化反应进 行优化, 实验因素与水平见表1.

以催化剂用量 $(\mathrm{A})$ 、醇酸摩尔比 $(\mathrm{B})$ 和反应温度 $(\mathrm{C})$ 为反应自变量, 其中自变量的编码值 1,0 和 -1 分别代表 自变量的高、中、低水平, 以产率为操作中的响应值, 由 $\mathrm{Y}$ 表示, 响应面试验方案及结果见表2. 实验4, 5, 8, 11 和 13 为 5 个中心实验, 用以估计实验误差, 其他为析因实验.

通过Design-Expert软件进行数据处理, 建立二次响 应面回归模型, 分析结果见表3和表4, 响应面图见图6.

各因素经回归拟合后, 得到回归方程如下:

$Y=95.66+1.00 A+11.90 B+5.55 C-0.37 A B-$

$$
0.18 A C-0.025 B C-3.97 A^{2}-11.07 B^{2}-5.27 C^{2}
$$

该模型进行方差分析结果见表 3 , 模型系数显著性 检验见表4. 由表3可以看出: $F$ 回归 $=3197>\left(F_{0.05}(9,4)\right.$ $=6.00), P<0.05$, 表明模型显著; $F$ 失拟 $=0.44<F_{0.05}(9$, $3)=8.1$, 失拟项 $P=0.74>0.05$, 模型失拟度不显著; 校 正决定系数 $R_{\text {adj }}^{2}>0.99$, 说明该模型能解释 $74 \%$ 响应值 的变化; 复相关系数 $R^{2}>0.99$ (接近 1$)$, 说明该模型拟合 程度良好, 试验误差小, 可用此模型对该反应进行分析 和预测.

对模型(3)解逆矩阵, 求得油酸甲酯产率的最大值为 $100 \%$, 此时催化剂用量为 $9.7 \%$, 醇酸摩尔比为 $3.4: 1$, 反 应温度为 $131.4{ }^{\circ} \mathrm{C}$. 为方便实验操作, 选取催化剂用量为 $10 \%$, 醇酸摩尔比为 $4: 1$, 反应温度为 $130{ }^{\circ} \mathrm{C}$, 所得油酸甲 酯产率为 $97.7 \%$, 与预测值接近, 说明该模型有效.

\section{7. $\left[\mathrm{BHSO}_{3} \mathrm{MIM}\right] \mathrm{HSO}_{4}$ 催化剂操作稳定性}

催化剂的操作稳定性直接影响连续化、自动化生产 过程, 具有较高操作稳定性的催化剂可反复利用多次, 从而降低油酸甲酯(生物柴油)的生产成本. 为考察催化 剂的可重复利用性, 本文在上述优化条件下研究了 $\left[\mathrm{BHSO}_{3} \mathrm{MIM} \mathrm{HSO}_{4}\right.$ 在催化油酸与甲醇酯化反应中的操 作稳定性. 由图7可知, $\left[\mathrm{BHSO}_{3} \mathrm{MIM}\right] \mathrm{HSO}_{4}$ 催化剂循环 使用 10 个批次(每批次使用 $4 \mathrm{~h}$ )后, 仍能保持其初始活性 的 $95.6 \%$, 反应 $4 \mathrm{~h}$ 后仍获较高油酸甲酯产率 $(93.2 \%)$, 表

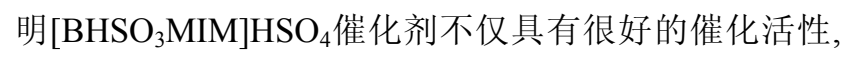
而且具有较高的操作稳定性.

\section{8. $\left[\mathrm{BHSO}_{3} \mathrm{MIM}\right] \mathrm{HSO}_{4}$ 催化不同原料转化为生物柴} 油

以上结果表明酸性离子液体 $\left[\mathrm{BHSO}_{3} \mathrm{MIM}\right] \mathrm{HSO}_{4}$ 能 高效地催化油酸与甲醇酯化反应合成油酸甲酯(生物柴 油). 为了进一步拓展该离子液体催化剂在不同原料中

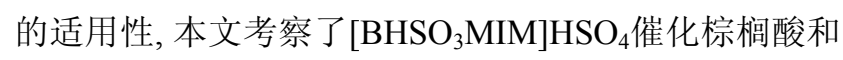
高酸值废油脂转化为生物柴油, 结果如表 5 所示. $\left[\mathrm{BHSO}_{3} \mathrm{MIM}\right] \mathrm{HSO}_{4}$ 也可高效催化棕榈酸与甲醇的酯化 反应, 在 $130{ }^{\circ} \mathrm{C} 反$ 应 $4 \mathrm{~h}$ 时, 获得 $94.7 \%$ 棕榈酸甲酯(生物 柴油). 值得注意的是, 以含 $72 \%$ 游离脂肪酸的废油脂为 原料, 在 $130{ }^{\circ} \mathrm{C}$ 时反应 $4 \mathrm{~h}$, 得到 $88.5 \%$ 生物柴油产率. $\left[\mathrm{BHSO}_{3} \mathrm{MIM}\right] \mathrm{HSO}_{4}$ 催化含高游离脂肪酸的废油脂转化 时发生酯化和转酯反应, 由于转酯反应速率明显慢于酯 化反应速率, 因此提高反应温度至 $140{ }^{\circ} \mathrm{C}$, $\left[\mathrm{BHSO}_{3} \mathrm{MIM}\right] \mathrm{HSO}_{4}$ 催化废油脂转化反应 $6 \mathrm{~h}$, 得到生物 柴油的产率提高至 $94.9 \%$. 可见, 酸性离子液体 $\left[\mathrm{BHSO}_{3} \mathrm{MIM}\right] \mathrm{HSO}_{4}$ 能高效地催化不同原料, 尤其是高酸 
值废油脂转化为生物柴油, 表现出巨大的应用潜力.

\section{4. 结论}

研究结果表明离子液体酸性越强, 其催化酯化活性 越高. 在所研究的酸性离子液体中, $\left[\mathrm{BHSO}_{3} \mathrm{MIM}\right] \mathrm{HSO}_{4}$ 催化油酸与甲醇酯化反应合成油酸甲酯(生物柴油)的效 果最好, 得到油酸甲酯的产率高达 $97.7 \%$. $\left[\mathrm{BHSO}_{3}\right.$ -
$\mathrm{MIM}] \mathrm{HSO}_{4}$ 不仅能有效地催化棕㭣酸与甲醇的酯化反 应, 还能高效地催化高酸值废油脂(含 $72 \%$ 游离脂肪酸) 转化为生物柴油, 表明该离子液体催化剂对不同原料生 产生物柴油方面具有很好的适用性, 展示出巨大的应用 潜力. 此外, 离子液体催化剂 $\left[\mathrm{BHSO}_{3} \mathrm{MIM}\right] \mathrm{HSO}_{4}$ 呈现出 极好的操作稳定性. 这为工业化生产生物柴油提供了一 种绿色安全的可行方法. 